\title{
Genotype-Dependent Differences between Cereals in Response to Manganese Excess in the Environment
}

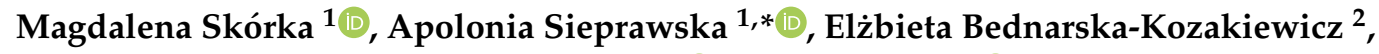 \\ Katarzyna Gawrońska ${ }^{1}$, Andrzej Kornaś ${ }^{1}$ (D) and Anna Telk ${ }^{3}$ (D) \\ 1 Institute of Biology, Pedagogical University, ul. Podchorążych 2, 31-084 Kraków, Poland; \\ magdalena.skorka1@student.up.krakow.pl (M.S.); katarzyna.gawronska@up.krakow.pl (K.G.); \\ andrzej.kornas@up.krakow.pl (A.K.) \\ 2 Faculty of Biology and Environmental Protection, Nicolaus Copernicus University, ul. Lwowska 1, \\ 87-100 Toruń, Poland; ebedn@umk.pl \\ 3 Faculty of Chemistry, Jagiellonian University, ul. Gronostajowa 2, 30-387 Kraków, Poland; \\ anna.telk@uj.edu.pl \\ * Correspondence: apolonia.sieprawska@up.krakow.pl
}

Received: 19 March 2020; Accepted: 30 March 2020; Published: 2 April 2020

\begin{abstract}
Industrial and agronomic activities lead to oversupply and accumulation of elements in the environment. Relatively little is known about mechanisms of manganese $(\mathrm{Mn})$ triggered stress. In this study, different cultivars of popular cereals wheat, oat, and barley were investigated for their response to excessive $\mathrm{Mn}$. Manganese ions $\left(\mathrm{MnCl}_{2}\right)$ at 5 and $10 \mathrm{mM}$ were applied to the grains and then to the media on which the plants grew until they developed their first leaf. It was performed ICP MS aiming to understand the mechanism of manganese stress in susceptible and resistant cultivar. Under Mn-stress a decrease in fresh weight of plants was observed, also differences in water content in first leaves, an increase in superoxide dismutases (SOD) and peroxidases (POX) activity, and a significant rise in catalase (CAT) was only characteristic for barley. Increasing Mn concentration resulted in enhancing of manganese superoxide dismutase (Mn-SOD) and copper, zinc superoxide dismutase $(\mathrm{Cu} / \mathrm{Zn}-\mathrm{SOD})$ bands intensity. The increase in proline content, depending on a balance between pyrroline-5-carboxylate synthase (P5CS), ornithine-d-aminotransferase (OAT), and proline dehydrogenases (PHD) activities, indicated osmotic disorders in all plants and differentiated the studied cereals. Microscopic observations of changes in the structure of plastids and starch accumulation in Mn presence were particularly visible in sensitive cultivars. The study ranked the tested cereals in terms of their tolerance to $\mathrm{Mn}$ from the most tolerant wheat through barley and the least tolerant oats.
\end{abstract}

Keywords: manganese; oxidative stress; osmoprotectants; wheat/barley/oats; enzyme activities

\section{Introduction}

An increasing demand for cereals, as one of the basic foods in the world, calls for genotypes that are resistant to various stress factors, leading for instance to disturbances in nutrient diffusion and mass flow in the soil. Furthermore, cereals need to adapt to changing climatic conditions such as a progressive global warming, with a limited amount of rainfall [1]. Another problem is an accumulation of significant amounts of elements in agricultural lands due to excessive fertilization. Enhanced levels of various elements, exceeding the plants' demand, generate oxidative stress resulting in reduced yield [2]. This also applies to the elements necessary for proper plant functioning such as $\mathrm{Fe}, \mathrm{Cu}, \mathrm{Zn}$, and $\mathrm{Mn}$, common components of enzymes involved in photosynthesis and antioxidative reactions. Subba et al. [3], Küpper et al. [4], Schützendübel, and Polle [5] showed that the excess of Fe, Cu, 
and Zn-stimulated stressogenic symptoms in plant tissues decreased their productivity. Relatively few articles have discussed Mn-triggered stress caused by an excess of this element in the soil [6-8] This element is present in the Earth's crust, soils, sediments and other biological materials, and its bioavailability depends on many factors including acidity, heat and genetic variation [6]. The average Mn value ranges from 450-4000 mg/kg [9]. Niu et al. [10] reported Mn soil contents in China in the range of $40-1681 \mathrm{mg} / \mathrm{kg}$, and Antibachi et al. [11] measured values ranging from $685-1307 \mathrm{mg} / \mathrm{kg}$ in soil from central Greece.

The importance of $\mathrm{Mn}$ in the cell functioning consists in its location in the active center of many enzymes [12], especially those that are involved in the regulation of redox properties being disturbed under stressful conditions and triggered by reactive oxygen species (ROS) [13]. However, Mn excess was reported to cause ROS formation, especially hydroxyl and superoxide radicals and hydrogen peroxide [14]. Toxicity of $\mathrm{Mn}$ in plant cells is manifested by a reduction in photosynthetic activity and inhibition of chlorophyll biosynthesis that finally diminish plant productivity [15]. Our earlier studies demonstrated that $\mathrm{Mn}$ accumulation in wheat cells was associated with reduced uptake of other micro- and macroelements, essential for proper plant growth and development [16]. Similar dependencies were also indicated by other authors in wheat $[17,18]$ and Arabidopsis thaliana $[19,20]$. Sieprawska et al. [21] suggested that Mn could accumulate in chloroplasts, and hence this would explain the significant effect as to modification of stress reactions associated with the generation of excess ROS in these organelles.

Presumably, a ROS surplus may lead to the activation of protective antioxidants of enzymatic and non-enzymatic origin [22]. Superoxide dismutases (SODs) catalyze the disproportionation reaction of the superoxide anion radical $\left(\mathrm{O}_{2}{ }^{--}\right)$, and catalases (CAT) and peroxidases (POX) eliminate hydrogen peroxide. Among non-enzymatic antioxidants, an increase in the synthesis of proline and sugars, also ensuring the stability of osmotic conditions, has been reported frequently [23]. Moreover, salicylic acid (SA) may provide protection against certain abiotic stresses, such as low/high temperature or heavy metal stress [24]. Significance of proline synthesis under stress, and its role in stabilizing the osmotic environment in plant cells, was demonstrated in many plants exposed to a metal-induced oxidative stress [25]. However, the mechanisms of this osmoprotectant synthesis are not fully understood, especially in view of the plant sensitivity to stress. Proline may be produced from glutamine by pyrroline-5-carboxylate synthetase (P5CS), or via the ornithine pathway by action of ornithine-d-aminotransferase (OAT). Its degradation is controlled by prolyl hydrohylase (PHD) [25]. Under abiotic stress it is mainly synthesized by P5CS enzymes [26]. An enhanced content of carbohydrates, serving as a source of energy essential for physiological processes was reported for many stresses [27], including heavy metals [28]. In fact, the synthesis of proline and carbohydrates has been suggested as a crucial element in plant stress survival strategy [29].

The aim of this study was to find similarities/differences in the protective mechanisms triggered by an excess of Mn, to identify specific factors mediating these mechanisms, and to identify the cereals most resistant to Mn oversupply. The stress sensitive and tolerant cultivars of three cereals most commonly used in agriculture and basis for many food products, i.e., wheat, barley, and oat were studied. Wheat is a principal crop in temperate regions used for both food and feed, and valued for high yield potential and adaptability [30]. Barley is the main food source in countries with extreme climates (e.g., deserts), and is economically advantageous [31]. Oat, with its grains rich in healthy substances is often considered "super-food" [32]. Biosafety of growing these crops requires maintaining appropriate breeding conditions, also consisting in a balanced level of ions present in the environment [33]. The research aims were realized through the following experiments: (i) Differentiation in Mn accumulation by grains; (ii) stimulation of antioxidant enzyme activation, with a particular focus on SOD-isoforms; (iii) changes in the concentration of substances that regulate cellular osmotic potential such as carbohydrates and proline, including the main enzymes of proline synthesis/degradation; (iv) SA content; and (v) microscopic observations of the cellular structure. 


\section{Materials and Methods}

Grains of spring wheat (cv. Parabola-tolerant and cv. Raweta-sensitive) and spring oats (cv. Bingo-tolerant, hulled and cv. Siwek-sensitive, naked) were received from the Polish Plant Breeding Stations Radzików and Strzelce. Spring barley two-rowed cultivars grains (cv. CAM/B1-tolerant and cv. Maresi-sensitive) were obtained from the International Center for Agricultural Research in the Dry Areas (ICARDA) and from Gene Bank in Prague, Czech Republic respectively. Selection of the tested cultivars was based on previous studies of their tolerance to various stress factors [34-36]. After sterilization with $80 \%$ ethanol and then $10 \%$ perhydrol, the grains were rinsed four times with distilled water. Sterilized grains placed in Petri dishes containing 0 (control), 5 and $10 \mathrm{mM}$ aqueous solutions of $\mathrm{MnCl}_{2}$, and germinated at $20^{\circ} \mathrm{C}$ in the dark. The applied doses of $\mathrm{Mn}$ were chosen based on our earlier experiments [21]. The Mn treated grains were put into pots filled with perlite hydrated with 5 or $10 \mathrm{mM} \mathrm{MnCl}_{2}$ solutions. Control grains were grown without Mn application. The pots were transferred into a greenhouse $\left(800 \mu \mathrm{mol}\right.$ (photons) $\mathrm{m}^{-2} \mathrm{~s}^{-1}, 16 \mathrm{~h}$ photoperiod at $22 / 17^{\circ} \mathrm{C}$; day/night), and cultured to reach the growth phase in which the first leaf emerged from the coleoptile (six days). After this time fresh and dry weight of the leaves was measured. The first leaves, about $2 \mathrm{~cm}$ long, were collected for biochemical analysis. Plant material from all tested plants was stored at $-80^{\circ} \mathrm{C}$. The experiment was repeated three times and five repetitions were performed within one experiment in all biochemical analyzes.

\subsection{Determination of Manganese Content via Biochemistry and Microscopy Assays}

The leaves were lyophilized (Freeze Dry System/Freezone 4.5, Labconco, USA) and samples of $0.02 \mathrm{~g}$ were mineralized in ultrapure concentrated nitric acid (Merck, Darmstadt, Germany) in a closed microwave system (Uni Clever, Plazmatronika, Poland). Mn (55) was analyzed by ICP-MS spectrometry (Elan DRC-e, Perkin Elmer, Shelton, USA), according the protocol described in details by Tobiasz et al. [37].

The first leaves of Parabola and Raweta cultivars obtained from control and $10 \mathrm{mM} \mathrm{MnCl} 2$ conditions were fixed in Carnoy's solution (glacial acetic acid: ethanol (100\%); 1:3 v/v), and filled with LR GOLD resin (Fluka LR Gold embedding kit for microscopy, Buchs, Switzerland) preceding the microscopic observations. The leaf profile was recorded using a BX50 microscope (Olympus, Tokyo, Japan) with NIS Elements AR 3.00 NIKON software, Tokyo, Japan).

\subsection{Antioxidant Enzyme Assays and Detection of Their Isoforms}

Leaves $(1 \mathrm{~g})$ were homogenized in a phosphate buffer (PB, pH 7) supplemented with 0.1 mM EDTA and centrifuged for $10 \mathrm{~min}$ at $10,000 \times g$. The enzyme activity was analyzed spectrophotometrically (Biochrom Ultrospec II, LKB, Sweden). Superoxide dismutase (SOD; EC 1.15.1.1) activity was determined with a cytochrome method [38]. The samples were mixed with the reaction mixture containing $1 \mathrm{mM}$ cytochrome c; $0.1 \mathrm{mM}$ EDTA; phosphate buffer $\mathrm{pH} 7.8$ and $1 \mathrm{mM}$ xanthine and analyzed at $\lambda=550 \mathrm{~nm}$. The amount of the enzyme necessary for $50 \%$ inhibition of cytochrome c (in a coupled system with xanthine and xanthine oxidase) was established as a unit of SOD activity. The activity of peroxidase (POX; EC 1.11.1.9) was detected using a modified method of Lúck [39] by measuring the quantity of p-phenylenediamine (1\%) reaction products in the presence of $\mathrm{H}_{2} \mathrm{O}_{2}$ $(0.03 \mathrm{mM})$ in PB at $\lambda=485 \mathrm{~nm}$. Catalase (CAT; EC 1.11.16) activity was detected according to Aebi [40], in the mixture of $\mathrm{PB}$ and $0.03 \mathrm{mM}$ hydrogen peroxide at $\lambda=240 \mathrm{~nm}$.

SOD isoforms were detected in the leaves of Parabola and Raweta cultivars. Fresh leaves $(1 \mathrm{~g})$ were homogenized in $8 \mathrm{~mL}$ of $100 \mathrm{mM}$ Tricine buffer ( $\mathrm{pH}$ 8.0) containing $3 \mathrm{mM} \mathrm{MgSO}_{4}, 1 \mathrm{mM}$ dithiothreitol (DTT), $3 \mathrm{mM}$ EDTA and 5\% polyvinylpolypyrrolidone (PVPP), and centrifuged for 3 min at 12,000 $\mathrm{g}$ at $4{ }^{\circ} \mathrm{C}$ Protein content was quantified according to Bradford [41]. Individual SOD-isoforms were separated using native polyacrylamide gel electrophoresis (PAGE) in the Laemmli [42] buffer system without sodium dodecyl sulfate (SDS). Samples containing $9 \mu \mathrm{g}$ of protein were loaded on a $12 \%$ gel. 
After electrophoresis $\left(4^{\circ} \mathrm{C}, 180 \mathrm{~V}\right)$, SOD bands were visualized using the staining method described by Beauchamp and Fridovich [43]. The gels were incubated in a staining buffer (PB with $10 \mathrm{mM}$ EDTA, $28 \mathrm{mM}$ tetramethylethylenediamine (TEMED), $22 \mathrm{mM}$ riboflavin and $0.25 \mathrm{mM}$ nitro blue tetrazolium (NBT); pH 7.8 for $20 \mathrm{~min}$ in darkness, and then exposed to white light until SOD activity bands became visible [44].

\subsection{Analysis of Proline Metabolism}

Proline was identified after homogenization $1 \mathrm{~g}$ of leaves in $3 \%$ aqueous solution of sulfosalicylic acid, and after centrifugation the supernatant was extracted with toluene $(4 \mathrm{~mL})$. Quantitative analysis was based on spectrometric technique (Evolution 201, Thermo Scientific), with ninhydrin reagent (1\% in $60 \%$ acetic acid), as presented by Bates et al. [45], and modified by Grzesiak et al. [34].

The samples for the determination proline enzymes assay were prepared according to Lútts et al. [46]. Their enzymatic activity was determined spectrophotometrically (Biochrom Ultrospec II, LKB, Sweden). D1-pyrroline-5-carboxylate synthase (P5CS; EC 2.7.2.11) was analyzed at $\lambda=340 \mathrm{~nm}$, according to Stines et al. [47]. Ornithine-d-aminotransferase (OAT; EC 2.6.1.68) was determined as described by Vogel and Kopac [48] at $\lambda=440 \mathrm{~nm}$. Proline dehydrogenase (PHD; EC 1.5.99.8) at $\lambda=340 \mathrm{~nm}$, according to Lútts at al. [46]. The enzymatic activity was expressed as a unit per $\mathrm{mg}$ protein. Protein content was determined according the Bradford [41], with bovine serum as a standard.

\subsection{Carbohydrate and Salicylic Acid Content}

Determination of soluble carbohydrates and starch was based on reactions with anthrone reagent as described by Janeczko et al. [49]. To degrade starch into glucose a medium containing 0.5 unit of amyloglucosidase (EC 3.2.1.3) and 1 unit of $\alpha$-amylase (EC 3.2.1.1) was used.

The samples for the determination of salicylic acid were prepared according to Warrier et al. [50], and centrifuged at $10,000 \times g$ for $10 \mathrm{~min}$. The supernatant $(100 \mu \mathrm{L})$ was mixed with ferric chloride $(0.1 \%)$. Salicylic acid content was determined spectrophotometrically (Biochrom Ultrospec II, LKB, Sweden), and absorbance was measured at $\lambda=540 \mathrm{~nm}$.

\subsection{Statistical Analysis of Data}

Data present the mean \pm SE. The statistical analysis involved Duncan's multiple-range test, and statistical significance was set at $p<0.05$ using PC SAS 8.0 software, (Tulsa, USA). Significance of the means was estimated using SAS ANOVA.

\section{Results}

Before analyzing the effects of Mn on the biochemical factors indicating stressogenic effects of this ion, the Mn content in the control grains was determined. The level of $\mathrm{Mn}$ ranged from about $6.34 \pm 0.02,9.10 \pm 0.04$ and $12.06 \pm 0.06 \mu \mathrm{g} \mathrm{g}^{-1} \mathrm{DW}$, for Parabola, CAM and Bingo, respectively, and $6.77 \pm 0.03,9.93 \pm 0.05$, and $13.11 \pm 0.03 \mu \mathrm{g}^{\circ} \mathrm{g}^{-1}$ for Raweta, Maresi and Siwek, respectively (Figure 1A). In all studied cereals, the application of Mn increased accumulation of this element in a dose-depending manner. At $5 \mathrm{mM} \mathrm{MnCl} 2 \mathrm{Mn}$ content increased by 7 and 9 fold for tolerant and sensitive genotypes, respectively, and at $10 \mathrm{mM} \mathrm{MnCl}_{2}$ by about 13 and 15 fold for tolerant and sensitive plants, respectively. A statistically significant differences were found in the $\mathrm{Mn}$ accumulation between sensitive and tolerant cultivars of all tested cereals. 

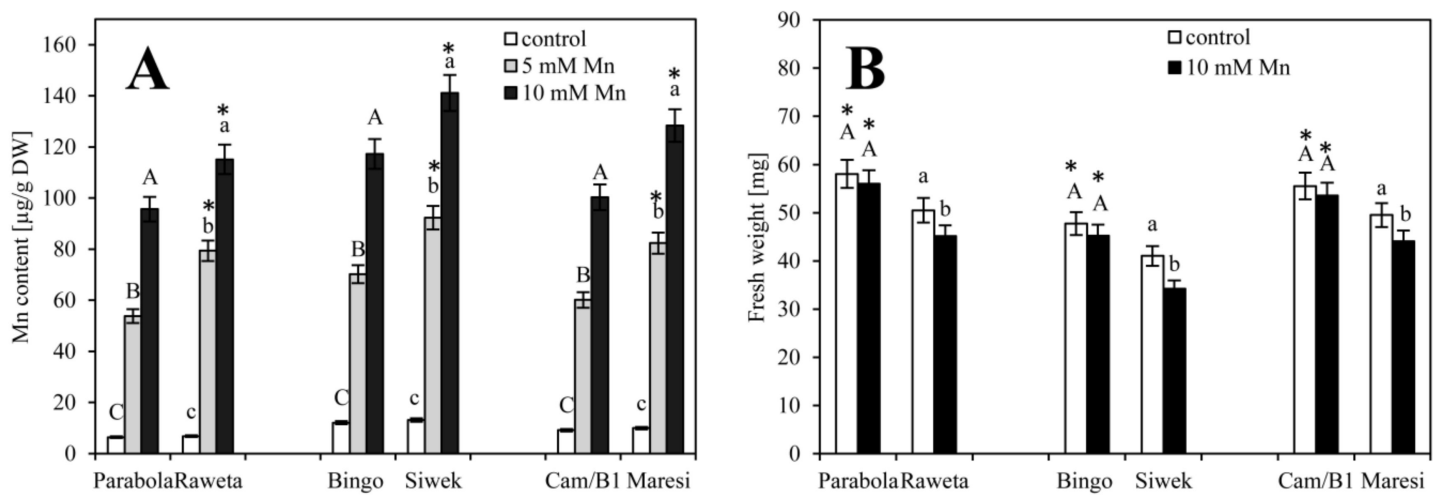

Figure 1. (A)-Manganese content $\left(\mu \mathrm{g} \cdot \mathrm{g}^{-1} \mathrm{DW}\right)$ in grains; (B) - fresh weight $[\mathrm{mg}]$ of the first leaves of wheat (Parabola-tolerant and Raweta-sensitive), oats (Bingo-tolerant and Siwek-sensitive) and barley (CAM/B1-tolerant and Maresi-sensitive) cultivars grown in water (control) and at 5 and $10 \mathrm{mM} \mathrm{MnCl}_{2}$. Values are mean of five replications $( \pm \mathrm{SE})$. Different letters indicate significant $(p<0.05)$ differences between treatments. Differences between cultivars are marked as "*”.

Fresh weight of the first leaf was higher in the tolerant cultivars than in the sensitive ones in all control objects, with the highest value in wheat (Figure 1B). A higher Mn dose decreased the fresh weight especially in the sensitive cultivars: By about $5 \mathrm{mg} /$ plant in Raweta and Maresi and about $7 \mathrm{mg} /$ plant in Siwek, while in all tolerant cultivars-by about $2 \mathrm{mg} /$ plant only. Calculated water content (differences between fresh and dry weight) in the leaves of tolerant and sensitive cultivars ranged between $80-82 \%$ and $79-82 \%$, respectively. All cultivars responded to a higher Mn dose with a drop in their water content, with the effect being particularly strong in the sensitive plants (about $69-74 \%$ ). All cultivars indicated as tolerant in our earlier works [34-36] were characterized by a statistically significant higher mass than that of sensitive ones, both in control conditions and under Mn treatment.

Figure 2 presents changes in the activity of the investigated antioxidant enzymes. Among the control objects, both wheat cultivars had the highest activity of SOD (Figure 2A) and POX (Figure 2B), barley showed the highest activity of CAT (Figure 2C), while in oats the activity of all studied enzymes was the lowest one. Both Mn concentrations enhanced SOD activity in all cereals. In the sensitive plants, a higher Mn dose nearly doubled the enzyme activity in comparison with the control. The increase in POX and CAT activity was observed in tolerant and sensitive wheat and barley seedlings, especially those exposed to $10 \mathrm{mM} \mathrm{MnCl}_{2}$. In the sensitive oat plants, a decrease in POX and CAT activity was noted, while in tolerant ones, Mn presence stimulated only POX activity. Moreover, POX activity of all sensitive cultivars under control conditions was greater than in tolerant ones. This contrasted with CAT, higher activity of which was registered in tolerant cultivars.

A detailed analysis of SOD isoforms in wheat leaves showed that in control conditions the enzyme was represented mainly by two isoforms: $\mathrm{Cu} / \mathrm{ZnSOD}$ and MnSOD (Figure 3). In both tolerant and sensitive cultivars, $\mathrm{Cu} / \mathrm{ZnSOD}$ bands became more visible in Mn-treated samples, with the changes being more pronounced in the sensitive plants. Similarly, the activity of MnSOD isoform increased after exposure to $\mathrm{Mn}$ ions, and at $10 \mathrm{mM} \mathrm{MnCl}_{2}$ the band representing this isoform was more visible than at $5 \mathrm{mM} \mathrm{MnCl}_{2}$. 

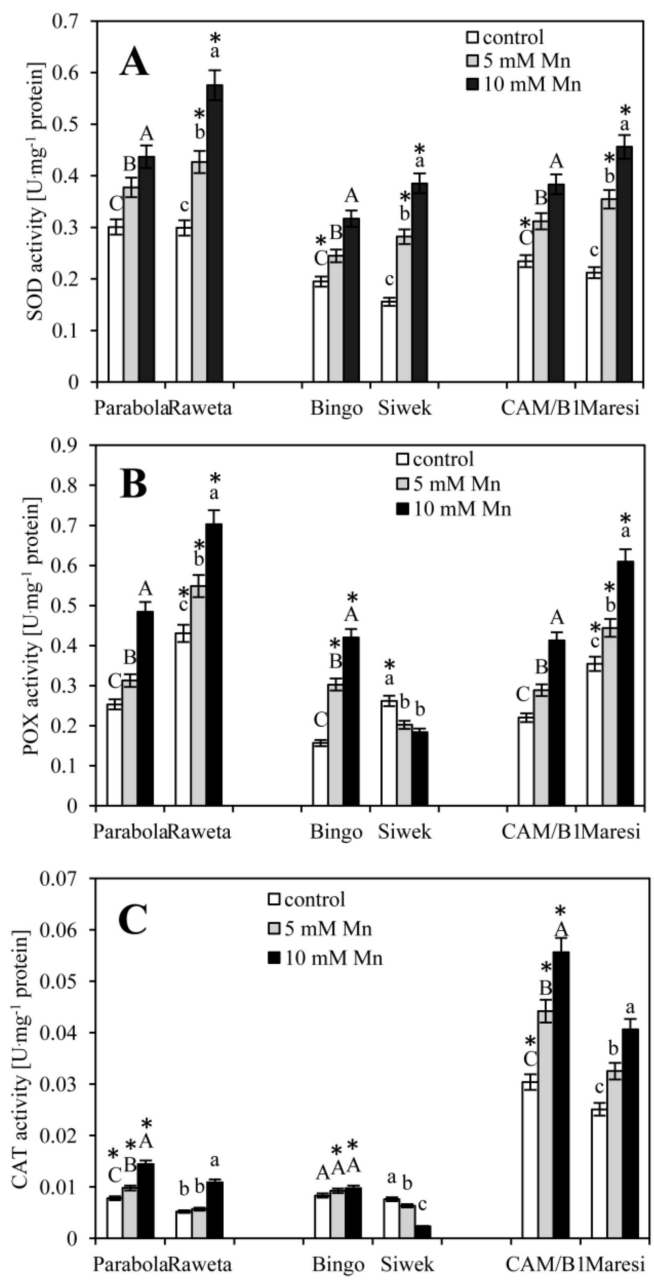

Figure 2. Activity of superoxide dismutases (SODs) (A), peroxidases (POX) (B), and catalase (CAT) (C) $[\mathrm{U} / \mathrm{mg}$ protein] in wheat (Parabola-tolerant and Raweta-sensitive), oats (Bingo-tolerant and Siwek-sensitive) and barley (CAM/B1-tolerant and Maresi-sensitive) cultivars, grown in water (control) and at 5 and $10 \mathrm{mM} \mathrm{MnCl}$. Values are mean of five replications $( \pm \mathrm{SE})$. Different letters indicate significant $(p<0.05)$ differences between treatments. Differences between cultivars are marked as "**".

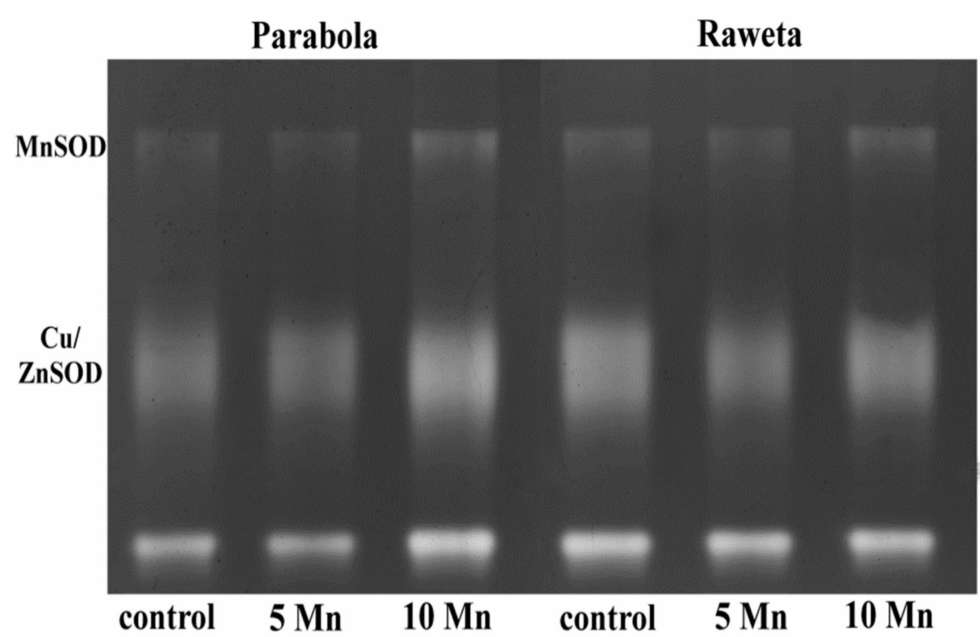

Figure 3. Patterns of SOD activity visualized by native PAGE in wheat leaves of Parabola and Raweta, grown in water (control) and at 5 and $10 \mathrm{mM} \mathrm{MnCl}_{2}$. 
The analysis of non-enzymatic antioxidants revealed that the salicylic acid (SA) concentration (Table 1) in control plants was generally higher in sensitive cultivars, and decreased in the order of wheat $>$ oat $>$ barley, irrespective of the plant tolerance. $\mathrm{MnCl}_{2}$ at $5 \mathrm{mM}$ significantly enhanced SA content in all tolerant plants, whereas at $10 \mathrm{mM}$ this change was smaller, especially for $\mathrm{cv}$. Bingo. An exception to this pattern was $\mathrm{cv}$. CAM/B1, where a higher Mn concentration triggered a greater increase in SA than the lower one. In sensitive wheat and oat, the content of SA decreased with increasing Mn accumulation. In Maresi some increase of SA was noted only at $5 \mathrm{mM} \mathrm{MnCl}_{2}$.

In control conditions the content of soluble sugars was higher in the sensitive cultivars. Starch was slightly less abundant in sensitive than in tolerant plants, with the exception of oats, where its concentration was higher in the sensitive cultivar (Table 1). In the presence of $\mathrm{Mn}$, the content of soluble sugars increased and reached the highest values at $10 \mathrm{mM} \mathrm{MnCl}{ }_{2}$ in tolerant cultivars, and at $5 \mathrm{mM} \mathrm{MnCl} 2$ in sensitive ones. Starch accumulation also raised in Mn exposed plants. For wheat its highest amounts were registered at $10 \mathrm{mM} \mathrm{MnCl}_{2}$, and for oats and barley it was cultivar-dependent, i.e., higher values were observed at $10 \mathrm{mM} \mathrm{MnCl}_{2}$ for tolerant vs. sensitive oat, while for barley a reverse relationship was noted.

Concentration of proline was similar in the control objects of all tolerant cultivars (Figure 4A). Sensitive cultivars, especially of barley and oat, accumulated more proline than the tolerant ones. Mn application resulted in a gradual increase of proline content with rising $\mathrm{Mn}$ doses. The only exception was cv. Siwek, where a small decrease in proline level at $10 \mathrm{mM}$ of $\mathrm{MnCl}_{2}$ (versus $5 \mathrm{mM} \mathrm{MnCl}$ ), was registered.
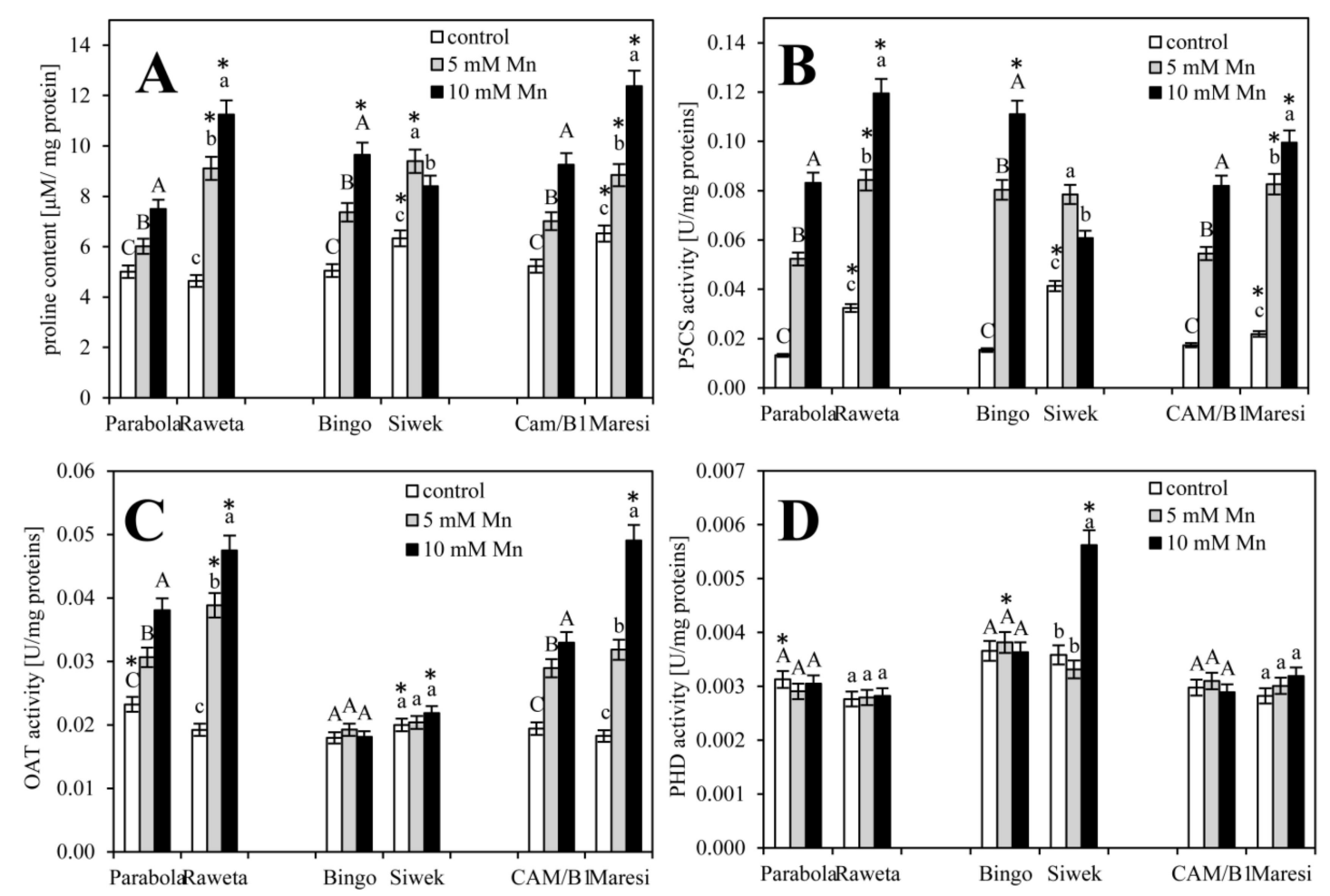

Figure 4. (A)-Proline content [ $\mu \mathrm{M} \cdot \mathrm{mg}^{-1}$ protein]; (B)-P5CS; (C)-OAT and (D)-PHD [U/mg protein] activity in the first leaves of wheat (Parabola-tolerant and Raweta-sensitive), oats (Bingo-tolerant and Siwek-sensitive) and barley (CAM/B1-tolerant and Maresi-sensitive) cultivars, grown in control and at 5 and $10 \mathrm{mM} \mathrm{MnCl}_{2}$. Values are mean of five replications $( \pm \mathrm{SE})$. Different letters indicate significant $(p<0.05)$ differences between treatments. Differences between cultivars are marked as "**". 
Table 1. Concentration of salicylic acid ( $\left.\mu \mathrm{g} \cdot \mathrm{g}^{-1} \mathrm{FW}\right)$, carbohydrates (mg.g $\left.{ }^{-1} \mathrm{DW}\right)$ and starch (mg/g DW) in the first leaves of wheat (Parabola-tolerant and Raweta-sensitive), oats (Bingo-tolerant and Siwek-sensitive) and barley (CAM/B1-tolerant and Maresi-sensitive) cultivars germinated in water (control) and at 5 and $10 \mathrm{mM} \mathrm{MnCl}_{2}$.

\begin{tabular}{|c|c|c|c|c|c|c|c|c|c|c|}
\hline \multicolumn{2}{|c|}{ Cultivar } & \multicolumn{3}{|c|}{ Salicylic Acid $\left[\mu \mathrm{g} \cdot \mathrm{g}^{-1} \mathrm{FW}\right]$} & \multicolumn{3}{|c|}{ Carbohydrates $\left[\mathrm{mg}^{-1} \mathrm{~g}^{-1} \mathrm{DW}\right]$} & \multicolumn{3}{|c|}{ Starch $\left[\mathrm{mg} \cdot \mathrm{g}^{-1} \mathrm{DW}\right]$} \\
\hline & & Control & $5 \mathrm{mMMn}$ & $10 \mathrm{mM} \mathrm{Mn}$ & Control & $5 \mathrm{mM} \mathrm{Mn}$ & $10 \mathrm{mM} \mathrm{Mn}$ & Control & $5 \mathrm{mM} M \mathrm{Mn}$ & $10 \mathrm{mM} \mathrm{Mn}$ \\
\hline \multirow{2}{*}{ Wheat } & Parabola & $0.29 \pm 0.09^{c}$ & $0.90 \pm 0.12 \mathrm{a}^{\mathrm{a}}{ }^{*}$ & $0.64 \pm 0.11^{\mathrm{b}}$ & $1.33 \pm 0.02^{b}$ & $1.44 \pm 0.02^{\mathrm{a}}$ & $1.48 \pm 0.03^{a}$ & $2.16 \pm 0.02^{b}, *$ & $2.17 \pm 0.02^{b}$ & $2.74 \pm 0.03$ a \\
\hline & Raweta & $0.73 \pm 0.10^{a}, *$ & $0.62 \pm 0.08^{b}$ & $0.52 \pm 0.07^{c}$ & $1.68 \pm 0.02 \mathrm{c}^{*}$ & $2.11 \pm 0.02 \mathrm{a}, *$ & $2.06 \pm 0.04 \mathrm{~b}^{\mathrm{b}, *}$ & $1.95 \pm 0.02^{c}$ & $2.14 \pm 0.02^{b}$ & $3.07 \pm 0.04^{a, *}$ \\
\hline \multirow{2}{*}{ Oat } & Bingo & $0.16 \pm 0.03^{b}$ & $0.22 \pm 0.02^{\mathrm{a}}$ & $0.17 \pm 0.02^{b, *}$ & $1.28 \pm 0.01^{c}$ & $1.27 \pm 0.05^{b}$ & $1.37 \pm 0.02^{\mathrm{a}}$ & $1.08 \pm 0.01^{\mathrm{c}}$ & $1.36 \pm 0.01^{b}$ & $1.75 \pm 0.01^{\mathrm{a}}$ \\
\hline & Siwek & $0.14 \pm 0.02^{\mathrm{a}}$ & $0.02 \pm 0.00^{\mathrm{b}}$ & $0.02 \pm 0.00^{\mathrm{b}}$ & $1.72 \pm 0.02 \mathrm{c}^{* *}$ & $2.40 \pm 0.02^{a}{ }^{*}$ & $2.06 \pm 0.02 \mathrm{~b}^{\mathrm{b}, *}$ & $1.12 \pm 0.01 \mathrm{c}^{*}$ & $2.00 \pm 0.02^{\mathrm{b}, *}$ & $1.87 \pm 0.02^{a}, *$ \\
\hline \multirow{2}{*}{ Barley } & CAM/B1 & $0.04 \pm 0.00^{\mathrm{c}}$ & $0.10 \pm 0.01^{b}$ & $0.34 \pm 0.02 \mathrm{a}{ }^{*}$ & $1.24 \pm 0.01^{\mathrm{a}}$ & $1.28 \pm 0.01^{\mathrm{a}}$ & $1.29 \pm 0.01^{\mathrm{a}}$ & $1.84 \pm 0.01 \mathrm{c}^{*}$ & $1.88 \pm 0.01^{\mathrm{a}}$ & $1.91 \pm 0.01 \mathrm{~b}$ \\
\hline & Maresi & $0.04 \pm 0.00^{b}$ & $0.19 \pm 0.02 \mathrm{a}^{\mathrm{a}^{*}}$ & $0.04 \pm 0.00^{\mathrm{b}}$ & $1.36 \pm 0.01 \mathrm{~b}^{, *}$ & $1.75 \pm 0.02 \mathrm{a}^{*}$ & $1.73 \pm 0.03 \mathrm{a}^{*}$ & $1.64 \pm 0.01^{\mathrm{c}}$ & $2.05 \pm 0.02^{b, *}$ & $3.03 \pm 0.03^{a_{r}{ }^{*}}$ \\
\hline
\end{tabular}

Values are mean of five replications ( \pm SE). Different letters indicate significant $(p<0.05)$ differences between treatments. Differences between cultivars are marked as “*”. FW-fresh weight, DW-drought weight. 
Figure 4B,C present the activity of enzymes involved in proline synthesis pathway. Control objects of tolerant cultivars showed lower P5CS activity than sensitive ones, with the lowest activity of this enzyme in Parabola (Figure 4B). In the sensitive cultivars, cv. Maresi exhibited the lowest activity of P5CS. Mn application significantly enhanced P5CS activity in all cultivars, especially at the higher dose. The only exception was cv. Siwek, where P5CS was slightly less active at 10 than at $5 \mathrm{mM} \mathrm{MnCl}$. OAT activity was similar in all control samples irrespective of the cultivar tolerance (Figure 4C). After Mn treatment, the enzyme activity increased in wheat and barley, and the increase was more pronounced at 10 than $5 \mathrm{mM}$ of $\mathrm{MnCl}_{2}$, while oats showed no significant differences between Mn treatments and control conditions. The activity of PHD in the control samples was the highest in oat leaves (Figure 4D). Mn application enhanced activity of this enzyme only in the sensitive cultivar of oat, and mainly at the higher dose, while in the other tested cultivars no significant changes were noted.

Microscopic observations showed similarities between the control samples of both tolerant (Figure 5A) and sensitive (Figure 5B) wheat leaves. In parenchymal cells, numerous plastids (arrows) were visible. Their oval shape indicated the presence of proplastids (Figure $5 \mathrm{~A}^{\prime}, \mathrm{B}^{\prime}$ ), while the more elongated shapes signaled the formation of chloroplasts (Figure 5A",A"', Figure 5B", $\mathrm{B}^{\prime \prime \prime}$ ). At $10 \mathrm{mM}$ $\mathrm{MnCl}_{2}$ numerous starch granules were visible in the plastids (stars) of cv. Parabola (Figure 5C). In the cells surrounding the vascular bundle, oval plastids with large starch granules were found (Figure $\left.5 C^{\prime}, C^{\prime \prime}\right)$, while the plastids of the cells distant from the vascular bundle contained smaller and more elongated starch grains (Figure 5C'”'). In cv. Raweta (Figure 5D), small oval proplastids (arrowheads, Figure 5D',D") were registered. In individual cells around the vascular bundle, plastids with large starch granules (star, Figure 5D"') were found and cells with plastids of elongated shape (arrow, Figure 5D") were also visible.
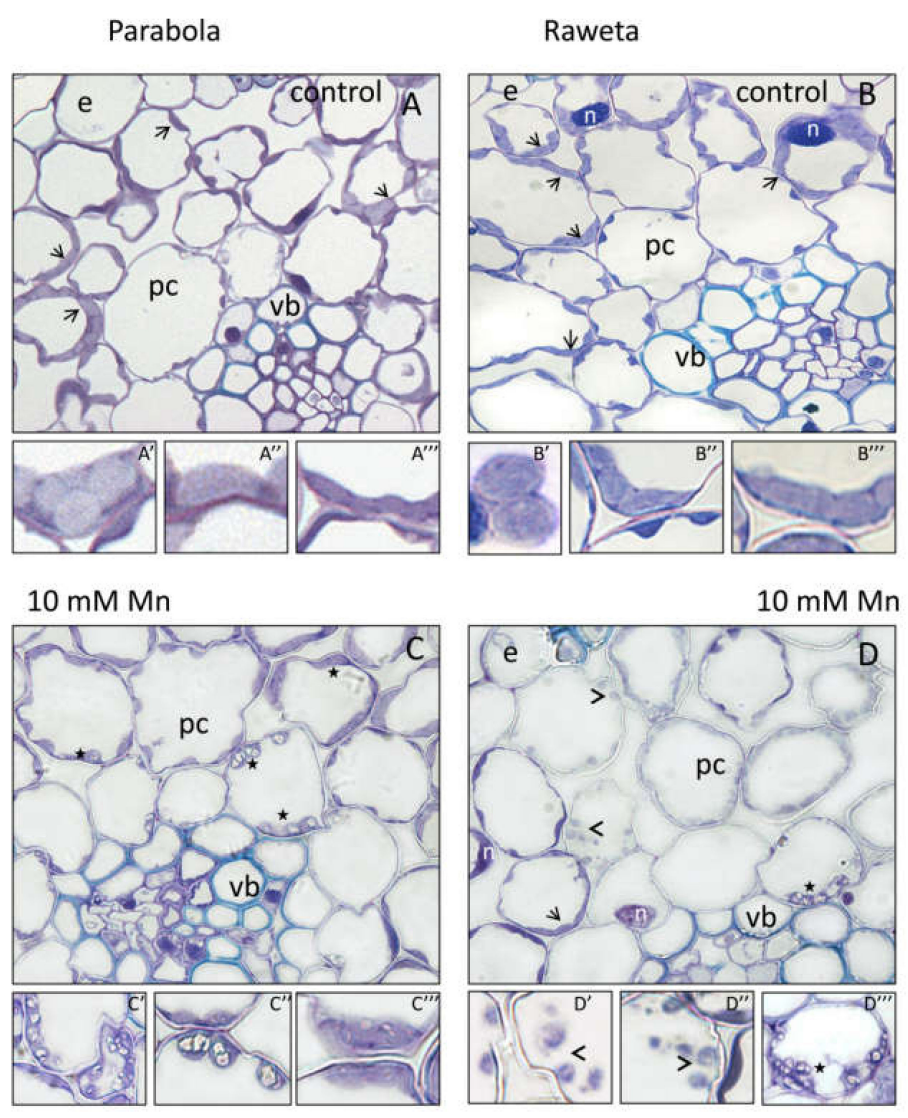

Figure 5. Example of leaf sections of Parabola and Raweta, in control and at $10 \mathrm{mM} \mathrm{MnCl}$. Inset shows magnified fragment with proplastides-marked by arrow and starch granules—marked by a star. Pc-parenchymatic cell, vb-vascular bundle, n-nucleus, e-epidermis. For (A-D) magnification was $40 \times$; for inset $100 \times$. 


\section{Discussion}

Mn ions were accumulated in the grains of all tested cultivars, thus pointing to a noteworthy ability of cereals to uptake this element from the culture media. Mn absorption at even higher amounts than shown in this study was also described by Millaleo et al. [12]. Already Izaguirre-Mayoral and Sinclair [51] confirmed the role of interspecific and phenotypic variations in crops after experimental overexposure to Mn. Fernando and Lynch [6] suggested that anthropogenic environmental effects may affect interactions between the plant and $\mathrm{Mn}$, and the nature of these changes is dynamic in shifting climate patterns. Greater Mn accumulation by sensitive cultivars may result from greater "permeability" of their cellular structures occurring in their seeds than of the tolerant ones. Such an explanation is in agreement with the experiments of Chatterjee and Nagarajan [52], who investigated wheat plants with different susceptibility to oxidative stress initiated by drought. They concluded that seeds of the tolerant cultivar showed lower permeability than of the sensitive one. This finding may be also supported with the data obtained by Kornaś et al. [53], where greater efflux of ions from the membranes of sensitive cereal cultivars suggested lower integrity of their membranes, affecting their better permeability.

A physiological indicator of Mn stress was fresh weight decrease in the seedlings developing in the presence of this metal. Weight change is a generally accepted parameter that denotes the intensity of stress factors [54]. A greater decrease in fresh weight in sensitive cultivars confirmed their larger susceptibility to Mn excess, and allowed us to tentatively identify oats as the most sensitive and wheat as the most resistant among the tested cereals. The other physiological symptoms of Mn stress included changes of water relations in the leaves of all cultivars, suggesting the occurrence of osmotic stress in the tissues. More pronounced changes of this parameter in sensitive cultivars (despite the similar water potential of control plants), confirmed the role of membrane structures and their permeability, as well as a possible role of osmoprotectants in the mechanism of anti-Mn-stress protective action. Similar relationships between water content and stress initiated by metal ions excess $(\mathrm{Cd}, \mathrm{Na})$ were found in bean by Rady [55].

We assumed that different responses of the studied cereals to Mn toxicity depended on how they "deal" with Mn-triggered oxidative stress. The initiation of oxidative stress is evidenced by activation of antioxidant enzymes [56]. Generally, Mn-treatments affected the activity of these enzymes in all cereals. Wheat seedlings showed the highest activity of SODs among all objects, even in control conditions. This may suggest a higher activity of wheat in capturing superoxide radicals, as compared with the remaining cereals. It may also explain the earlier suggestions based on fresh weight and an article by Shewry [30] of high resistance of wheat to Mn stress. As for POX and CAT-two enzymes involved in hydrogen peroxide decomposition-it seems that in wheat and oats the process was controlled mainly by POX, while in barley by both enzymes. The inclusion of both POX and CAT in de-oxidation processes in barley may result in a more effective removal of ROS excesses under Mn-induced stress. The previously suggested largest sensitivity of oats to Mn excess [57] can be associated with its relatively low ability to activate all antioxidant enzymes, especially in the stress conditions. Decreased POX and CAT activity in the sensitive oat cultivar may indicate possible damage to their protein structure by powerful ROS action. This is an indirect evidence of a significant lack of tolerance in this cultivar.

Determination of SOD, the enzyme involved in scavenging one of the most reactive ROS (superoxide anion radical), was already reported for wheat leaves in numerous studies $[21,58]$. Therefore, the analysis of the activity of individual SOD-isoforms was performed for this cereal. The fact that apart from commonly occurring $\mathrm{Cu} / \mathrm{ZnSOD}, \mathrm{MnSOD}$ was also activated by $\mathrm{Mn}$ stress, suggests the importance of mitochondrial protection under these conditions. MnSOD is widely distributed in prokaryotic and eukaryotic organisms and is most often found in the mitochondrial matrix [59]. Mitochondria and chloroplasts are the main places of physiological and stress-induced cellular ROS production. In this study, we analyzed the youngest leaf (developing from germinating seeds), in which cell divisions are more intense than in the well expanded leaves. Microscopic observations of 
these leaves revealed the presence of numerous proplastids being chloroplast precursors. This may explain the lack of FeSOD band in the polyacrylamide gels, as this isoform is usually localized in mature chloroplasts.

The analysis revealed also differences in the size and shape of plastids between tolerant and sensitive wheat cultivars as well as the appearance of large starch granules in these organelles. Greater starch accumulation, induced by $\mathrm{Mn}$ application, indicated the disturbance of metabolic processes initiated under stress conditions [60], and was typical of all sensitive cultivars.

Increased concentration of non-enzymatic antioxidants (soluble sugars, proline) in Mn presence confirms that oxidative stress is accompanied by osmotic stress. Accumulation of greater amounts of these substances observed in the sensitive cultivars may indicate higher intensity of stress in these objects. The increase in proline level under metal-stress was suggested earlier by Sharma and Dubey [56]. Proline is a known osmoprotectant that in the presence of increased concentration of $\mathrm{Mn}$ ions protects the cells from losing water. Its content reflects a balance between the expression of enzymes responsible for its synthesis (P5CS and OAT) and its degradation (PHD). Metal stress stimulated both P5CS and OAT synthesis, as reported by Dar et al. [25]. In the present study, the increase in these enzymes activity was visible in wheat and barley, while in oats only P5CS activity was triggered. Lack of activation of proline degradation enzymes (PHD), observed in all tested cultivars (except for the sensitive oats), suggested the importance of high proline concentrations in Mn-exposed plants. In sensitive oats, the increase in PHD activity, detected at higher Mn dose, led to the reduction in proline level, and further to the loss of Mn tolerance. Moreover, the lowest synthesis of soluble sugars, the presence of which is, similarly as of proline, associated with the maintenance of optimal osmotic conditions, may indicate that low tolerance of oats may be related to cellular water management disorders.

Changes of salicylic acid content are usually considered as engagement of chemical signals in the control of plant responses under environmental stress [61]. The rise of SA synthesis under Mn stress in the tolerant cultivars correlated with lower Mn accumulation in the cells as opposed to the susceptible cultivars, where SA content decreased under stress and growing Mn uptake. Similar dependences were described by Wang et al. [62], thus suggesting that salicylic acid can control the uptake of some elements, such as $\mathrm{Mn}, \mathrm{Cu}, \mathrm{Fe}$, and $\mathrm{Zn}$. The share of these metals in the active centers of enzymes determines the efficiency of cellular detoxification mechanisms.

The statistically significant higher activity of enzymes both involved in detoxification as well as maintaining osmotic homeostasis in susceptible cells vs tolerant varieties may result of higher Mn accumulation. Zhang et al. [63] suggested that high metal concentrations cause increased ROS generation. Perhaps that is why in the majority of susceptible cultivars higher levels of enzymes both involved in cell detoxification as well as in maintaining adequate osmotic pressure were demonstrated. The exception is the oat Siwek at which the highest metal accumulation could cause irreversible metabolic dysfunctions (including reduction of enzyme activity) which were particularly evident in fresh mass reduction under Mn stress conditions.

\section{Conclusions}

Based on the described experiments it can be concluded that ability to uptake and accumulate this metal in the cells of the studied cereal genotypes is one of the first stages of a plant-Mn relationship, just as was suggested earlier by Kornaś et al. [53]. All cultivars sensitive to oxidative stress showed higher Mn uptake than the tolerant ones, and the physiological effects included inhibited growth and reduced leaf water content. Mn-stress resulted in a disorder of cellular metabolism revealed in microscopic observation as changes in the plastid structure and accumulation of significant amounts of starch, especially visible in the sensitive cultivars. It was demonstrated the increase of SOD activity both $\mathrm{Cu} / \mathrm{ZnSOD}$ and MnSOD isoforms in the presence of Mn. The POX is mainly activated in wheat and oats whereas CAT-in barley. The Mn ions caused osmotic disturbances, indicated as increase in the synthesis of soluble sugars and proline. Proline synthesis was genotype-dependent. In wheat and 
barley both glutamate and ornithine pathways were activated, whereas in oats only the glutamate pathway. Moreover, in the sensitive oat cultivar the higher dose of Mn significantly activated the enzyme responsible for proline degradation that could consequently weaken cellular protection in this cultivar. The increase of salicylic acid concentration was another factor involved in the mechanism of antioxidant protection against the toxic effects of Mn. Particularly high amounts of this substance found in wheat could provide additional path of defense of this cereal exposed to manganese stress.

Author Contributions: Conceptualization, M.S. and A.S.; Formal analysis, M.S., E.B.-K., K.G. and A.T.; Supervision, A.K.; Visualization, A.S.; Writing—original draft, M.S. and A.S.; Writing—review and editing, M.S., A.S. and K.G. All authors have read and agreed to the published version of the manuscript.

Funding: This work was supported by a grant from the National Science Center, Poland, Project No. 2013/11/D/ST4/02839.

Conflicts of Interest: The authors declare no conflict of interest.

\section{References}

1. Brito, C.; Dinis, L.T.; Moutinho-Pereira, J.; Correia, C.M. Drought stress effects and olive tree acclimation under a changing climate. Plants 2019, 8, 232. [CrossRef] [PubMed]

2. Keunen, E.; Remans, T.; Bohler, S.; Vangronsveld, J.; Cuypers, A. Metal-induced oxidative stress and plant mitochondria. Int. J. Mol. Sci. 2011, 12, 6894-6918. [CrossRef] [PubMed]

3. Subba, P.; Mukhopadhyay, M.; Mahato, S.K.; Bhutia, K.D.; Mondal, T.K.; Ghosh, S.K. Zinc stress induces physiological, ultra-structural and biochemical changes in mandarin orange (Citrus reticulata Blanco) seedlings. Physiol. Mol. Biol. Plants 2014, 20, 461-473. [CrossRef] [PubMed]

4. Küpper, H.; Götz, B.; Mijovilovich, A.; Küpper, F.C.; Meyer-Klaucke, W. Complexation and toxicity of copper in higher plants. I. Characterization of copper accumulation, speciation, and toxicity in Crassula helmsii as a new copper accumulator. Plant Physiol. 2009, 151, 702-714.

5. Schützendübel, A.; Polle, A. Plant responses to abiotic stresses: Heavy metal-induced oxidative stress and protection by mycorrhization. J. Exp. Bot. 2002, 53, 1351-1365. [CrossRef] [PubMed]

6. Fernando, D.R.; Lynch, J.P. Manganese phytotoxicity: New light on an old problem. Ann. Bot. 2015, 116, 313-319. [CrossRef]

7. Santos, E.F.; Santini, J.M.K.; Paixão, A.P.; Júnior, E.F.; Lavres, J.; Campos, M.; dos Reis, A.R. Physiological highlights of manganese toxicity symptoms in soybean plants: Mn toxicity responses. Plant Physiol. Bioch. 2017, 113, 6-19. [CrossRef]

8. Liu, P.; Huang, R.; Hu, X.; Jia, Y.; Li, J.; Luo, J.; Liu, Q.; Luo, L.; Liu, G.; Chen, Z. Physiological responses and proteomic changes reveal insights into Stylosanthes response to manganese toxicity. BMC Plant Biol. 2019, 19, 212. [CrossRef]

9. Li, J.; Jia, Y.; Dong, R.; Huang, R.; Liu, P.; Li, X.; Chen, Z. Advances in the mechanisms of plant tolerance to manganese toxicity. Int. J. Mol. Sci. 2019, 20, 5096. [CrossRef]

10. Niu, L.L.; Yang, F.X.; Xu, C.; Yang, H.Y.; Liu, W.P. Status of metal accumulation in farmland soils across China: From distribution to risk assessment. Environ. Pollut. 2013, 176, 55-62. [CrossRef]

11. Antibachi, D.; Kelepertzis, E.; Kelepertsis, A. Heavy metals in agricultural soils of the Mouriki-Thiva area (Central Greece) and environmental impact implications. Soil Sediment Contam. 2012, 21, 434-450. [CrossRef]

12. Millaleo, R.; Ivanov, A.G.; Mora, M.L.; Alberdi, M. Manganese as essential and toxic element for plants: Transport, accumulation and resistance mechanisms. J. Soil Sci. Plant Nut. 2010, 10, 476-494. [CrossRef]

13. Kurdziel, M.; Dłubacz, A.; Wesełucha-Birczyńska, A.; Filek, M.; Łabanowska, M. Stable radicals and biochemical compounds in embryos and endosperm of wheat grains differentiating sensitive and tolerant genotypes-EPR and Raman studies. J. Plant Phys. 2015, 183, 95-107. [CrossRef] [PubMed]

14. Srivastava, S.; Dubey, R.S. Manganese-excess induces oxidative stress, lowers the pool of antioxidants and elevates activities of key antioxidative enzymes in rice seedlings. Plant Growth Regul. 2011, 64, 1-16. [CrossRef]

15. Shi, Q.; Zhu, Z. Effects of exogenous salicylic acid on manganese toxicity, element contents and antioxidative system in cucumber. Environ. Exp. Bot. 2008, 63, 317-326. [CrossRef] 
16. Sieprawska, A.; Filek, M.; Tobiasz, A.; Walas, S.; Dudek-Adamska, D.; Grygo-Szymanko, E. Trace elements' uptake and antioxidant response to excess of manganese in in vitro cells of sensitive and tolerant wheat. Acta Physiol. Plant. 2016, 38, 55. [CrossRef]

17. Dimkpa, C.O.; Singh, U.; Adisa, I.O.; Bindraban, P.S.; Elmer, W.H.; Gardea-Torresdey, J.L.; White, J.C. Effects of manganese nanoparticle exposure on nutrient acquisition in wheat (Triticum aestivum L.). Agronomy 2018, 8, 158. [CrossRef]

18. Marschner, P. Marschner's Mineral Nutrition of Higher Plants, 3rd ed.; Academic Press: Boston, MA, USA, 2012.

19. Millaleo, R.; Reyes-Diaz, M.; Alberdi, M.; Ivanov, A.G.; Krol, M.; Huner, N.P. Excess manganese differentially inhibits photosystem I versus II in Arabidopsis thaliana. J. Exp. Bot. 2013, 64, 343-354. [CrossRef]

20. Socha, A.L.; Guerinot, M.L. Mn-euvering manganese: The role of transporter gene family members in manganese uptake and mobilization in plants. Front. Plant Sci. 2014, 5, 106. [CrossRef]

21. Sieprawska, A.; Filek, M.; Tobiasz, A.; Bednarska-Kozakiewicz, E.; Walas, S.; Dudek-Adamska, D.; Grygo-Szymanko, E. Response of chloroplasts of tolerant and sensitive wheat genotypes to manganese excess: Structural and biochemical properties. Acta Physiol. Plant. 2017, 39, 6. [CrossRef]

22. Gill, S.S.; Tuteja, N. Reactive oxygen species and antioxidant machinery in abiotic stress tolerance in crop plants. Plant Physiol. Biochem. 2010, 48, 909-930. [CrossRef] [PubMed]

23. Kavi Kishor, P.B.; Sreenivasulu, N. Is proline accumulation per se correlated with stress tolerance or is proline homeostasis a more critical issue? Plant Cell Environ. 2014, 37, 300-311. [CrossRef] [PubMed]

24. Metwally, A.; Finkemeier, I.; Georgi, M.; Dietz, K.J. Salicylic acid alleviates the cadmium toxicity in barley seedlings. Plant Physiol. 2003, 132, 272-281. [CrossRef] [PubMed]

25. Dar, M.I.; Naikoo, M.I.; Rehman, F.; Naushin, F.; Khan, F.A. Proline accumulation in plants: Roles in stress tolerance and plant development. In Osmolytes and Plants Acclimation to Changing Environment: Emerging Omics Technologies; Iqbal, N., Nazar, R., Eds.; Springer: New Delhi, India, 2016; pp. 155-166.

26. Amini, S.; Ghobadi, C.; Yamchi, A. Proline accumulation and osmotic stress: An overview of P5CS gene in plants. J. Plant Mol. Breed. 2015, 3, 44-55.

27. Kameli, A.; Lösel, D.M. Carbohydrates and water status in wheat plants under water stress. New Phytol. 1993, 125, 609-614. [CrossRef]

28. Tabuchi, A.; Kikui, S.; Matsumoto, H. Differential effects of aluminium on osmotic potential and sugar accumulation in the root cells of Al-resistant and Al-sensitive wheat. Physiol. Plant. 2004, 120, 106-112. [CrossRef]

29. Sidhu, G.P.S.; Singh, H.P.; Batish, D.R.; Kohli, R.K. Alterations in photosynthetic pigments, protein, and carbohydrate metabolism in a wild plant Coronopus didymus L. (Brassicaceae) under lead stress. Acta Physiol. Plant. 2017, 39, 176. [CrossRef]

30. Shewry, P.R. Wheat. J. Exp. Bot. 2009, 60, 1537-1553. [CrossRef]

31. Verstegen, H.; Köneke, O.; Korzun, V.; von Broock, R. The world importance of barley and challenges to further improvements. In Biotechnological Approaches to Barley Improvement; Springer: Berlin/Heidelberg, Germany, 2014; pp. 3-19.

32. Rasane, P.; Jha, A.; Sabikhi, L.; Kumar, A.; Unnikrishnan, V.S. Nutritional advantages of oats and opportunities for its processing as value added foods-a review. J. Food. Sci. Technol. 2015, 52, 662-675. [CrossRef]

33. Curtis, T.; Halford, N.G. Food security: The challenge of increasing wheat yield and the importance of not compromising food safety. Ann. App. Biol. 2014, 164, 354-372. [CrossRef]

34. Grzesiak, M.; Filek, M.; Barbasz, A.; Kreczmer, B.; Hartikainen, H. Relationships between polyamines, ethylene, osmoprotectants and antioxidant enzymes activities in wheat seedlings after short-term PEG- and NaCl-induced stresses. Plant Growth Regul. 2013, 69, 177-189. [CrossRef]

35. Łabanowska, M.; Kurdziel, M.; Filek, M.; Wesełucha-Birczyńska, A. The impact of biochemical composition and nature of paramagnetic species in grains on stress tolerance of oat cultivars. J. Plant Physiol. 2016, 199, 52-66. [CrossRef]

36. Filek, M.; Łabanowska, M.; Kurdziel, M.; Wesełucha-Birczyńska, A.; Bednarska-Kozakiewicz, E. Structural and biochemical response of chloroplasts in tolerant and sensitive barley genotypes to drought stress. J. Plant Phys. 2016, 207, 61-72. [CrossRef] [PubMed]

37. Tobiasz, A.; Walas, S.; Filek, M.; Mrowiec, H.; Samsel, K.; Sieprawska, A.; Hartikainen, H. Effect of selenium on distribution of macro-and micro-elements to different tissues during wheat ontogeny. Biol. Plant. 2014, 58, 370-374. [CrossRef] 
38. McCord, J.M.; Fridovich, I. Superoxide dismutase an enzymatic function for erythrocuprein (hemocuprein). J. Biol. Chem. 1969, 244, 6049-6055. [PubMed]

39. Lück, H. Methods of Enzymatic Analysis, 1st ed.; Bergmeyer, H.U., Ed.; Verlag Chemie GmbH: Weinheim/Bergstr, Germany; Academic Press: Cambridge, MA, USA, 1963; Volume 1, pp. 895-897.

40. Aebi, H. Catalase in vitro. Methods Enzymol. 1984, 105, 121-126. [PubMed]

41. Bradford, M.M. A rapid and sensitive method for the quantitation of microgram quantities of protein utilizing the principle of protein-dye binding. Anal. Biochem. 1976, 72, 248-254. [CrossRef]

42. Laemmli, U.K. Cleavage of structural proteins during the assembly of the head of bacteriophage T4. Nature 1970, 227, 680-685. [CrossRef]

43. Beauchamp, C.; Fridovich, I. Superoxide dismutase: Improved assays and an assay applicable to acrylamide gels. Anal. Biochem. 1971, 44, 276-287. [CrossRef]

44. Gawrońska, K.; Gołębiowska-Pikania, G. The effects of cold-hardening and Microdochium nivale infection on oxidative stress and antioxidative protection of the two contrasting genotypes of winter triticale. Eur. Food Res. Technol. 2016, 242, 1267-1276. [CrossRef]

45. Bates, L.S.; Waldren, R.P.; Teare, I.D. Rapid determination of free proline for water-stress studies. Plant Soil 1973, 39, 205-207. [CrossRef]

46. Lütts, S.; Majerus, V.; Kinet, J.M. NaCl effects on proline metabolism in rice (Oryza sativa) seedlings. Physiol. Plant. 1999, 105, 450-458. [CrossRef]

47. Stines, A.P.; Naylor, D.J.; Høj, P.B.; Heeswijck, R. Proline accumulation in developing grapevine fruit occurs independently of changes in the levels of $\Delta 1$-pyrroline-5-carboxylate synthetase mRNA or protein. Plant Physiol. 1999, 120, 923-931. [CrossRef] [PubMed]

48. Vogel, R.H.; Kopac, M.J. Some properties of ornithine- $\gamma$-transaminase from neurospora. Biochem. Biophys. Acta 1960, 37, 539-540. [CrossRef]

49. Janeczko, A.; Biesaga-Kościelniak, J.; Oklestkova, J.; Filek, M.; Dziurka, M.; Szarek-Łukaszewska, G.; Kościelniak, J. Role of 24- epibrassinolide in wheat production: Physiological effects and uptake. J. Agron. Crop Sci. 2010, 196, 311-321. [CrossRef]

50. Warrier, R.R.; Paul, M.; Vineetha, M.V. Estimation of salicylic acid in Eucalyptus leaves using spectrophotometric methods. Genet. Plant Physiol. 2013, 3, 90-97.

51. Izaguirre-Mayoral, M.L.; Sinclair, T.R. Soybean genotypic difference in growth, nutrient accumulation and ultrastructure in response to manganese and iron supply in solution culture. Ann. Bot. 2005, 96, 149-158. [CrossRef]

52. Chatterjee, N.; Nagarajan, S. Evaluation of water binding, seed coat permeability and germination characteristics of wheat seeds equilibrated at different relative humidities. Indian J. Biochem. Biophys. 2006, 43, 233-238.

53. Kornaś, A.; Filek, M.; Sieprawska, A.; Bednarska-Kozakiewicz, E.; Gawrońska, K.; Miszalski, Z. Foliar application of selenium for protection against the first stages of mycotoxin infection of crop plant leaves. J. Sci. Food Agric. 2019, 99, 482-485. [CrossRef]

54. Jaleel, C.A.; Manivannan, P.; Wahid, A.; Farooq, M.; Al-Juburi, H.J.; Somasundaram, R.; Panneerselvam, R. Drought stress in plants: A review on morphological characteristics and pigments composition. Int. J. Agric. Biol. 2009, 11, 100-105.

55. Rady, M.M. Effect of 24-epibrassinolide on growth, yield, antioxidant system and cadmium content of bean (Phaseolus vulgaris L.) plants under salinity and cadmium stress. Sci. Hortic. 2011, 129, 232-237. [CrossRef]

56. Sharma, P.; Dubey, R.S. Drought induces oxidative stress and enhances the activities of antioxidant enzymes in growing rice seedlings. Plant Growth Regul. 2005, 46, 209-221. [CrossRef]

57. Sharma, P.; Jha, A.B.; Dubey, R.S.; Pessarakli, M. Reactive oxygen species, oxidative damage, and antioxidative defense mechanism in plants under stressful conditions. J. Bot. 2012, 2012, 217037. [CrossRef]

58. Filek, M.; Łabanowska, M.; Kurdziel, M.; Sieprawska, A. Electron paramagnetic resonance (EPR) spectroscopy 24-epibrasinoide and selenium against zearalenone-stimulation of the oxidative stress in germinating grains of wheat. Toxins 2017, 9, 178. [CrossRef] [PubMed]

59. Alscher, R.G.; Erturk, N.; Heath, L.S. Role of superoxide dismutases (SODs) in controlling oxidative stress in plants. J. Exp. Bot. 2002, 53, 1331-1341. [CrossRef]

60. Thalmann, M.; Santelia, D. Starch as a determinant of plant fitness under abiotic stress. New Phytol. 2017, 214, 943-951. [CrossRef] 
61. Shakirova, F.M.; Sakhabutdinova, A.R.; Bezrukova, M.V.; Fatkhutdinova, R.A.; Fatkhutdinova, D.R. Changes in the hormonal status of wheat seedlings induced by salicylic acid and salinity. Plant Sci. 2003, 164, 317-322. [CrossRef]

62. Wang, C.; Zhang, S.; Wang, P.; Hou, J.; Qian, J.; Ao, Y.; Lu, J.; Li, L. Salicylic acid involved in the regulation of nutrient elements uptake and oxidative stress in Vallisneria natans (Lour.) Hara under Pb stress. Chemosphere 2011, 84, 136-142. [CrossRef]

63. Zhang, F.Q.; Wang, Y.S.; Lou, Z.P.; Dong, J.D. Effect of heavy metal stress on antioxidative enzymes and lipid peroxidation in leaves and roots of two mangrove plant seedlings (Kandelia candel and Bruguiera gymnorrhiza). Chemosphere 2007, 67, 44-50. [CrossRef]

(C) 2020 by the authors. Licensee MDPI, Basel, Switzerland. This article is an open access article distributed under the terms and conditions of the Creative Commons Attribution (CC BY) license (http://creativecommons.org/licenses/by/4.0/). 